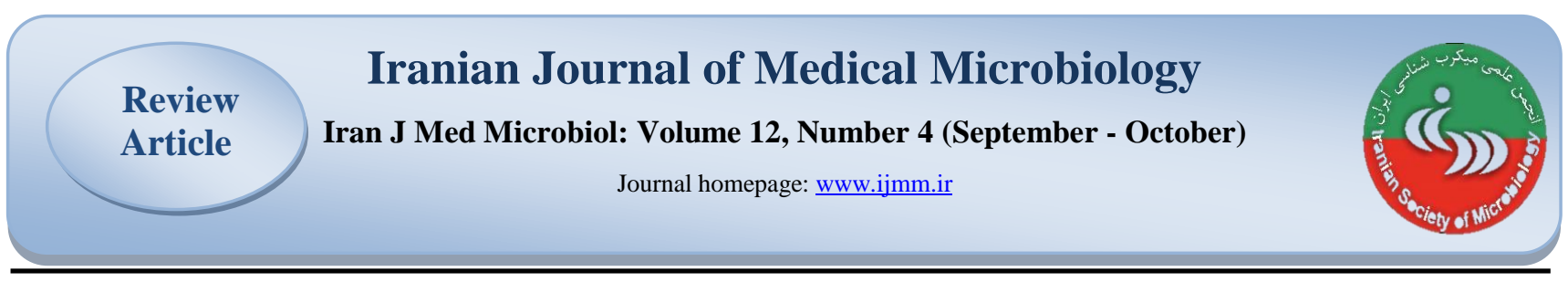

\title{
History of Bacterial Infection Diseases in Iran
}

\author{
Akbar Mirsalehian*", Mosayeb Dalvand ${ }^{2}$ \\ 1. Professor, Department of Basic Sciences, Iranian Academy of Medical Sciences, Tehran, Iran \\ 2. Expert, Department of Microbiology, School of Medicine, Tehran University of Medical Sciences, Tehran, Iran
}

\section{Article Information}

\section{Article history:}

Received: 2018/07/16

Accepted: 2018/11/03

Available online: $2018 / 11 / 23$

\section{Article Subject:}

Medical Bacteriology

IJMM 2018; 12(4): 230-238

Corresponding author:

\section{Akbar Mirsalehian}

Professor, Department of Basic

Sciences, Iranian Academy of

Medical Sciences, Tehran, Iran

Email:

mirsaleh@sina.tums.ac.ir

Use your device to scan and read the article online

\section{Abstract}

Many of the texts referenced by faculty members and medical students are from foreign sources and references, and the history of contagious diseases and the unique role of the country's scientists in the identification, treatment and control of these diseases has been forgotten. This paper attempts to review the history of prevalent bacterial infections in Iran. In this regard, it was attempted to review the scientific literature, including historical books and articles, with the historical background of prevalent bacterial infectious diseases such as cholera, leprosy, plague, tuberculosis, etc., as well as those who are hard-working and have played a significant role in difficult conditions trying to reduce the suffering of the people at that time. A review of the history of prevalent bacterial infectious diseases in Iran leading to the historical background of these diseases to be detailed in the book "History of Microbiology and Bacterial Infectious Diseases in Iran" is under the supervision of the Academy of Medical Sciences. Editing of scientific resources and academic books related to this issue should be based on the history of prevalent infectious diseases in Iran, so that in the future this historic cultural disadvantage would be corrected in an appropriate way.

Keywords: History, Bacterial infection, Prevention

Copyright @ 2018 Iranian Journal of Medical Microbiology. All rights reserved.

How to cite this article:

Mirsalehian A, Dalvand M. History of Bacterial Infection Diseases in Iran. Iran J Med Microbiol. 2018; 12 (4): 230-238 


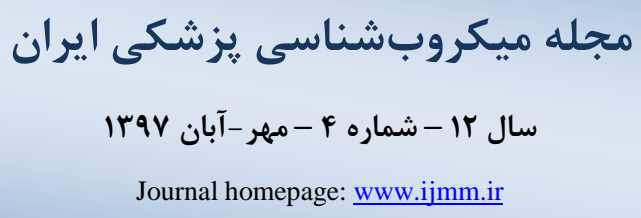

\section{تاريخجهُ بيمارىهاى عفونى باكتريايى شايع در ايران

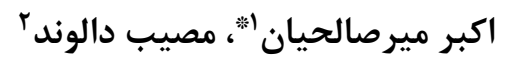

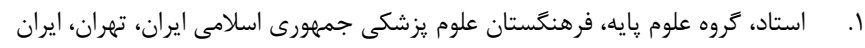

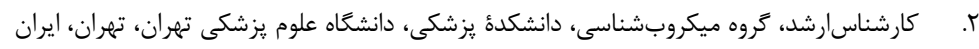

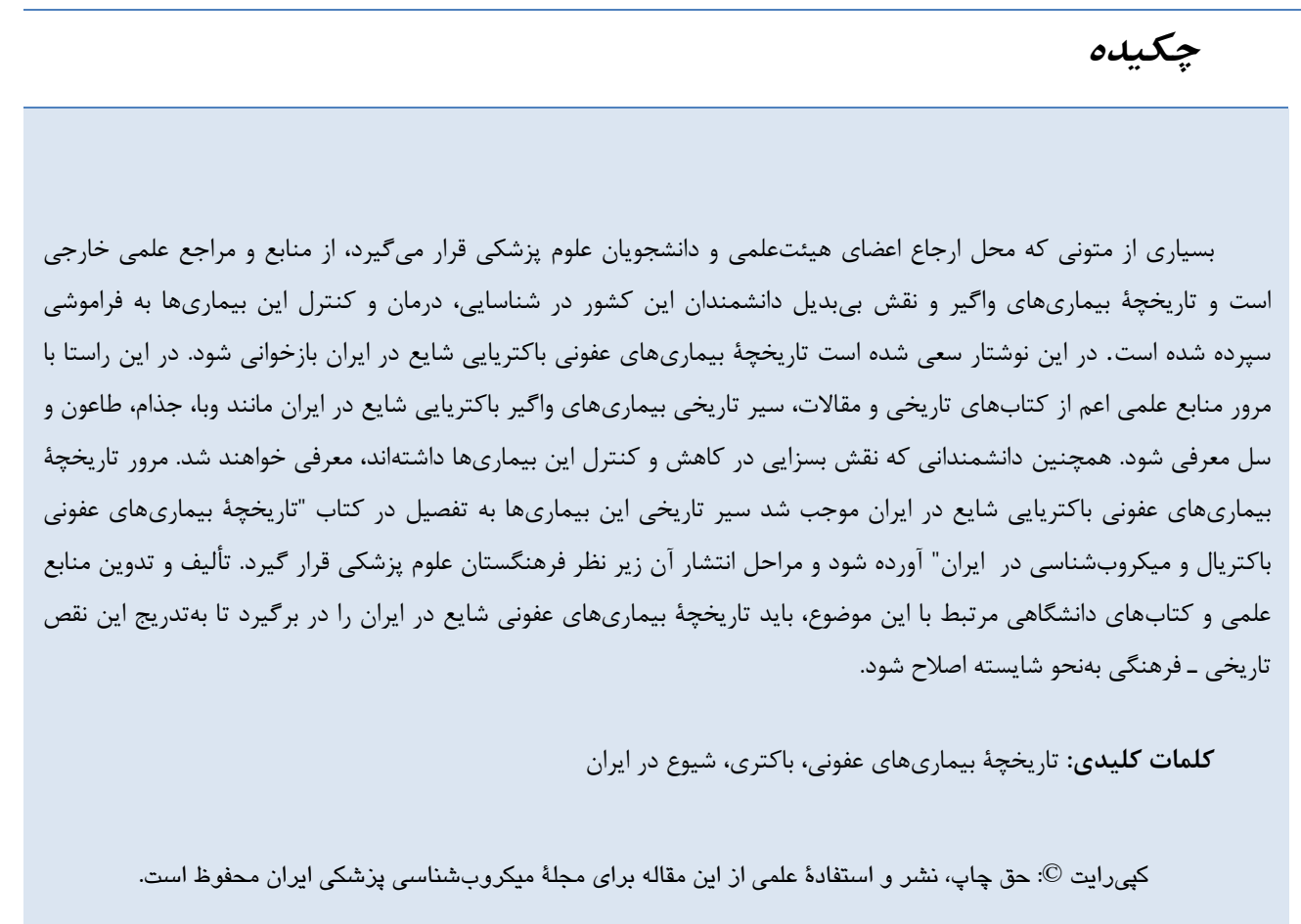

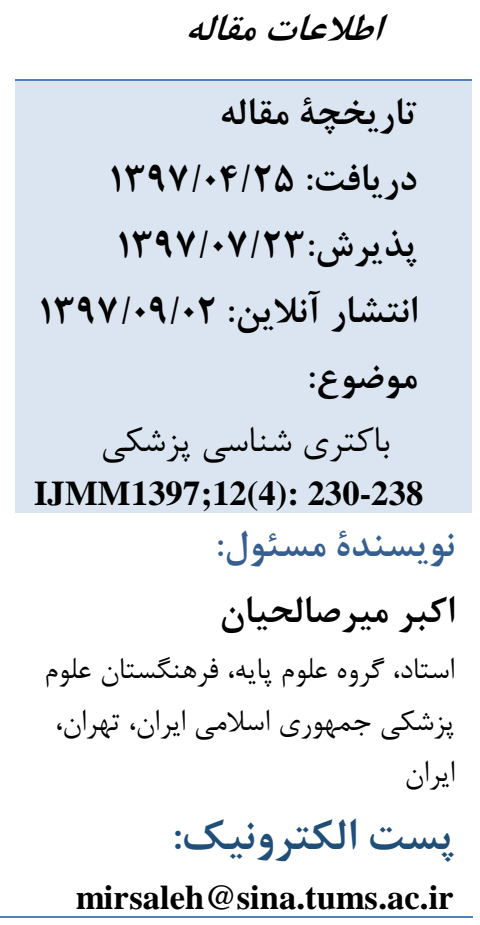

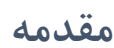

دانشكاهى، اين نقص تاريخى - فرهنگى بلنحو مقتضى رفع شود.

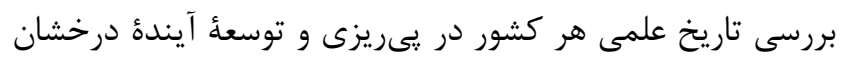

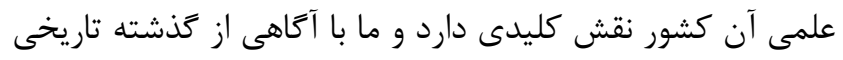

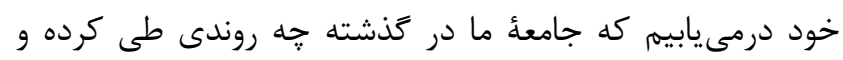

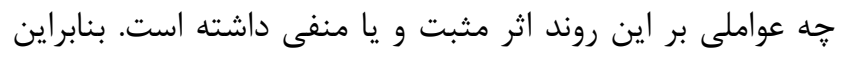

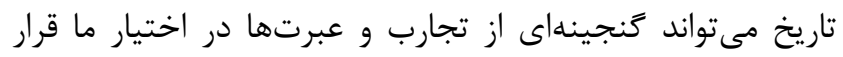

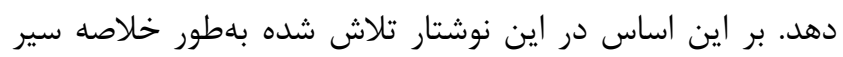
تاريخى بيمارىهاى عفونى باكتريايى در ايران بررسى شود.

$$
\text { بيمارىهاى عفونى واتير در ايران }
$$

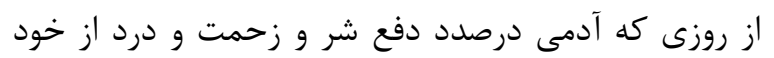

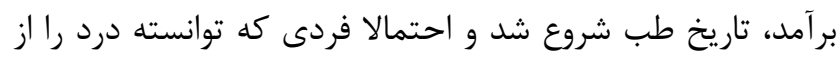

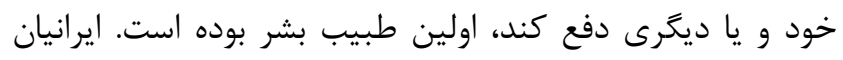

در منابع علمى و كتابهاى دانشآهى از تاريخجه صدمات

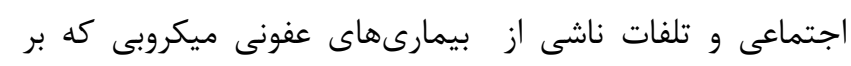

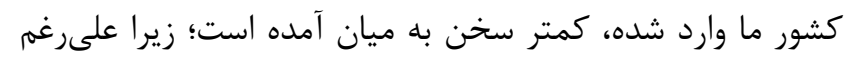

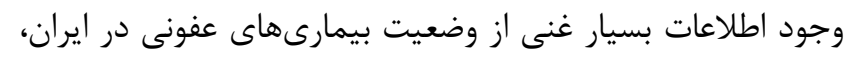

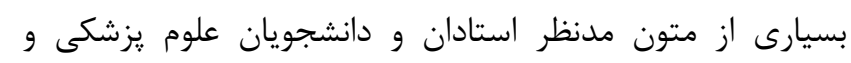

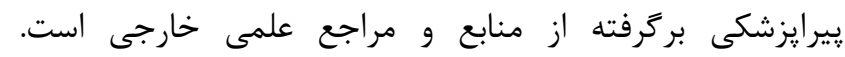

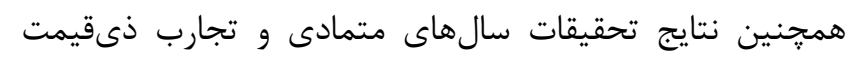

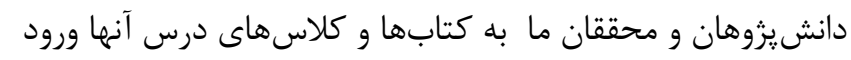

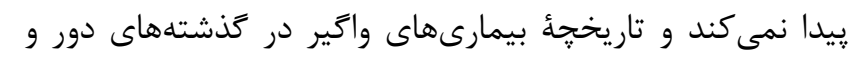

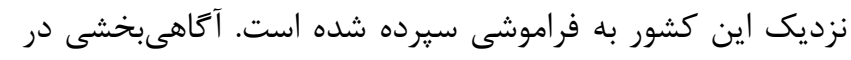

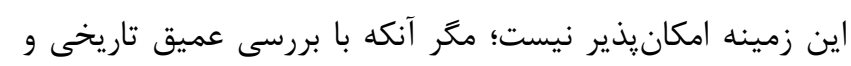

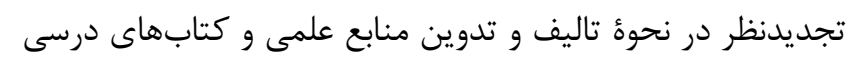


شواهد كافى از وجود بيمارى براى دورههاى زمانى طولانى

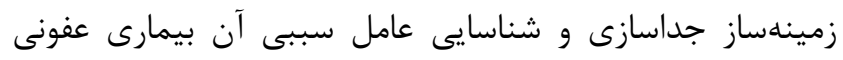

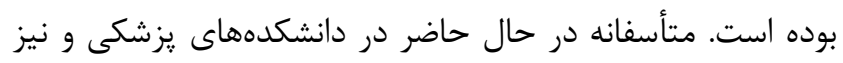

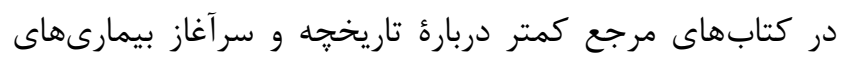

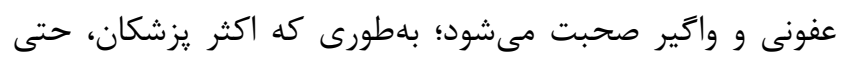

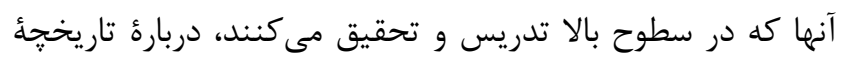

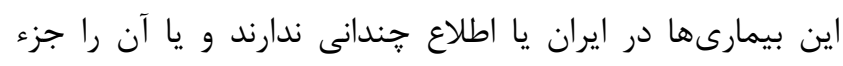

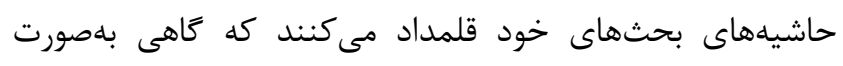

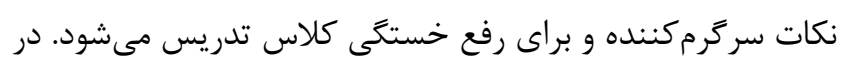

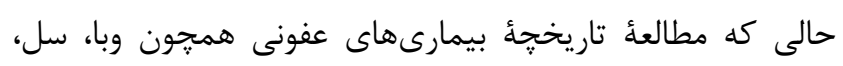

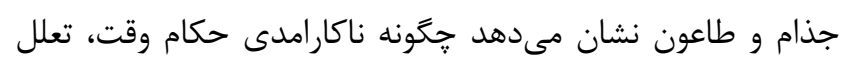

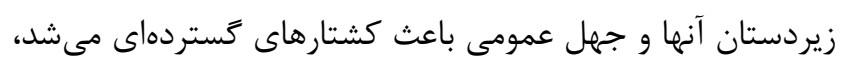

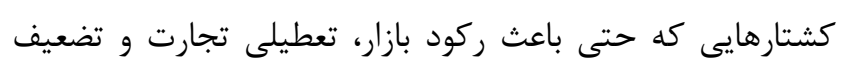

$$
\text { اقتدار ملى ايران مىشده است (r، r.r). }
$$

\section{وبا}

"ويليام مكنيل " William H. McNeill) در كتابى كه קند دها پيش با عنوان "وباها و مردم" منتشر كرد، مى گويد التاريخ

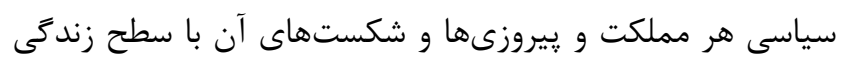

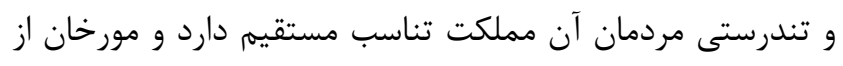

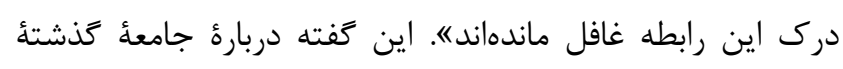

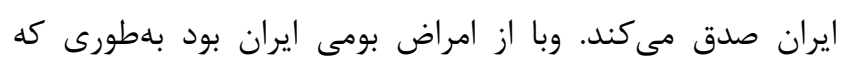

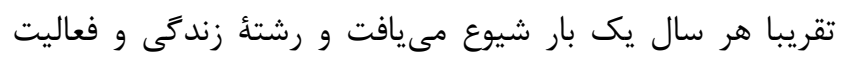

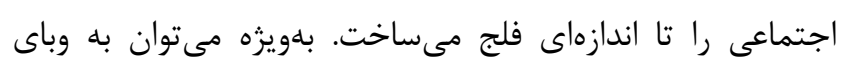

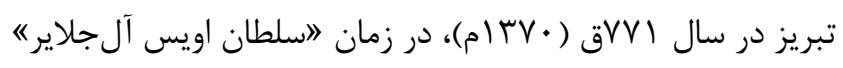

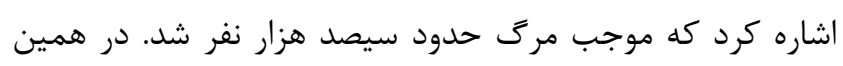

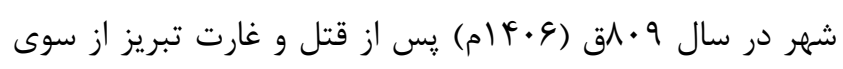

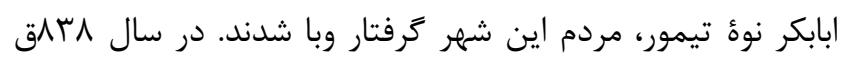

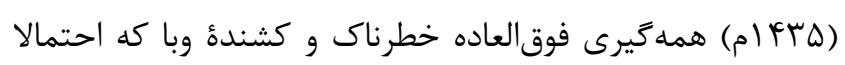

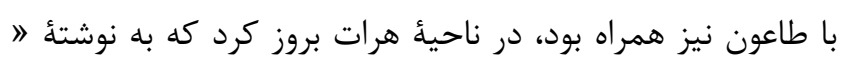

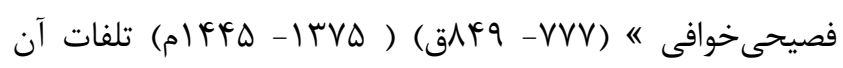
حدود 99 درصد بود (از هر دويست نفر يكى زنده ماند). بيمارى با

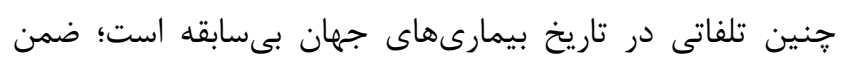

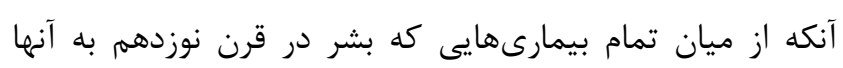

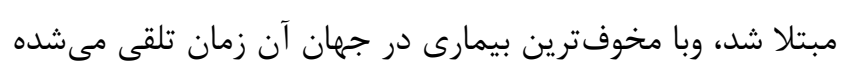

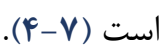

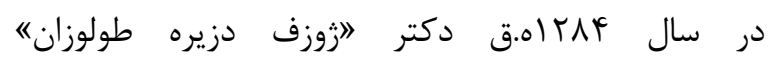
يزشك مخصوص ناصرالدينشاه (Joseph Désiré Tholozan)

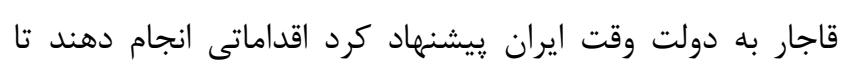

باستان هرجند بيمارى و درمان را امرى ماوراءالطبيعه تلقى

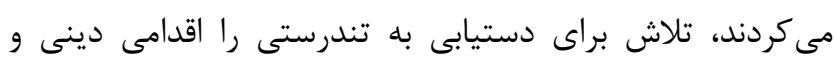

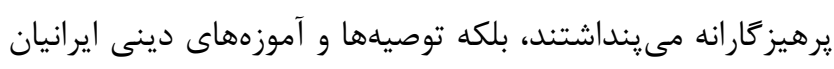

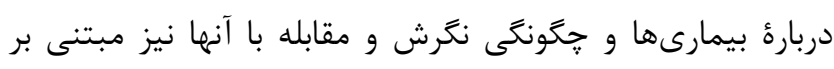

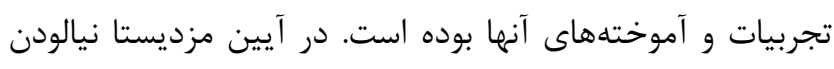

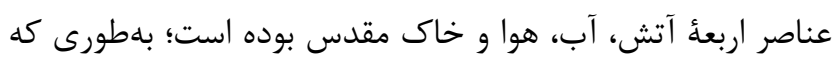

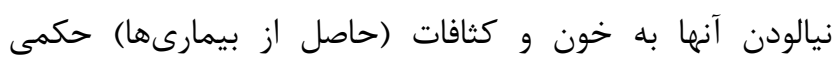

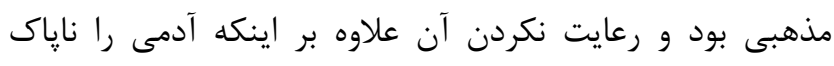

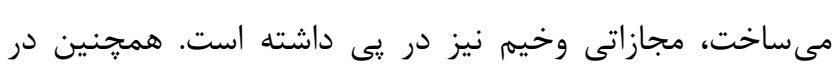

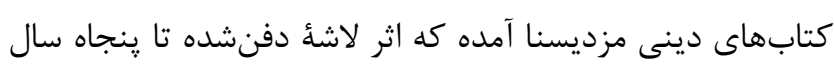

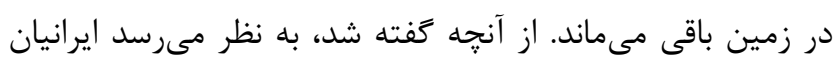

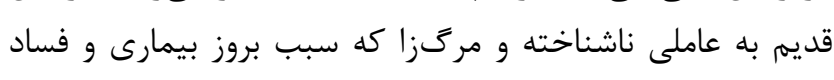

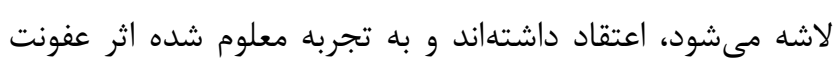

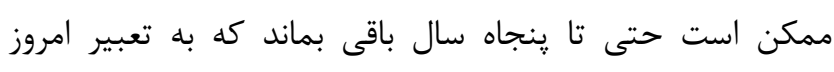

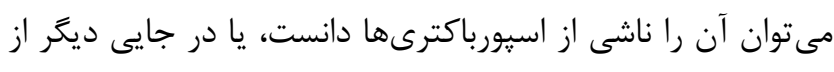

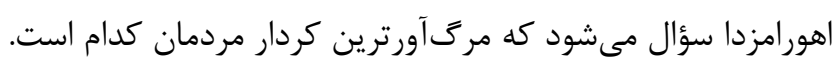

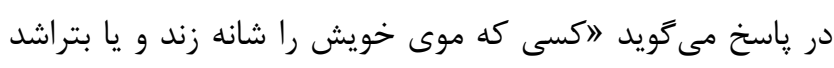

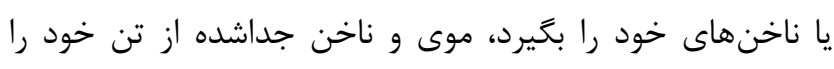

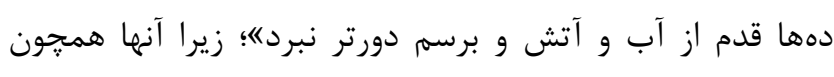

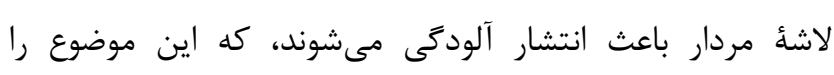

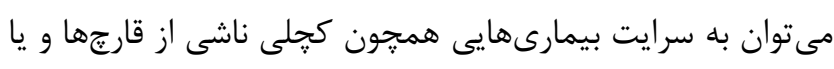

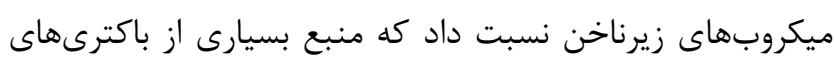

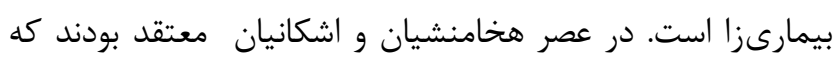

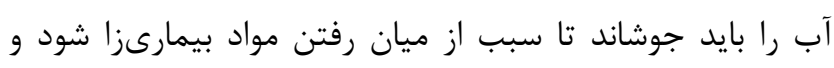

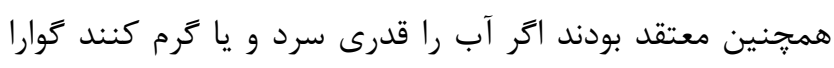

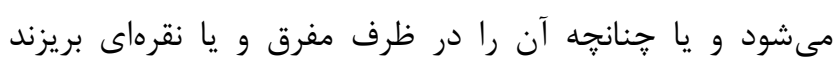

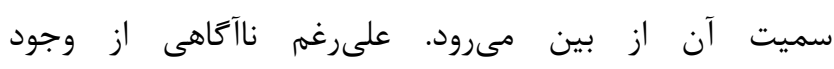

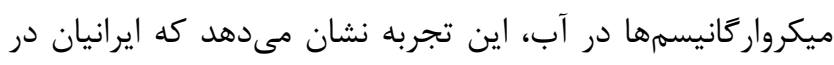

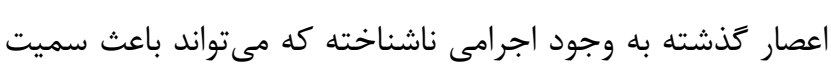

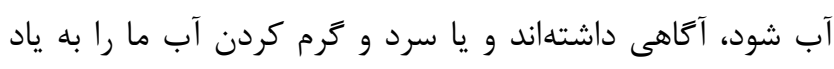

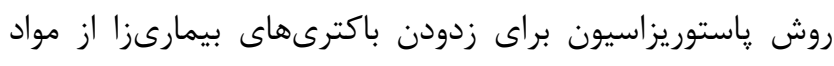

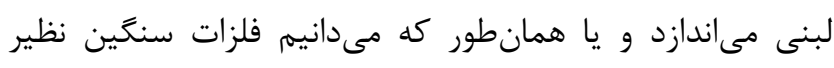

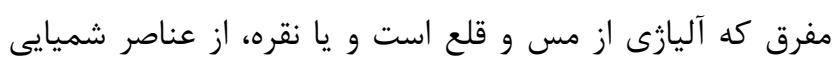

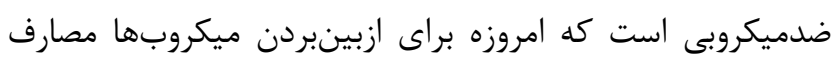
فراوانى در بهداشت و ضدعفونى كنندهها دارد.

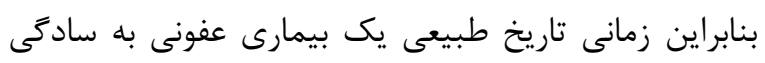

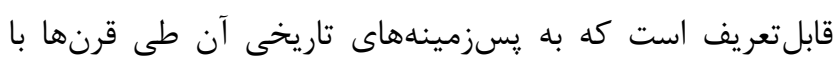

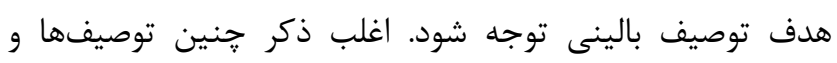


مهاجرت مىكردند و اكثرا براى هميشه ماندكار مىشدند، محلى

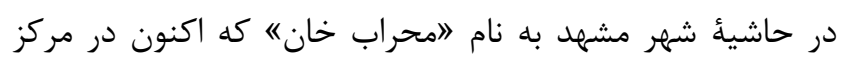

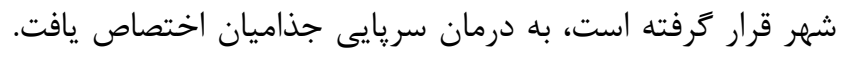

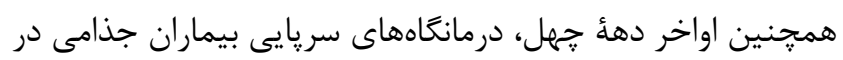

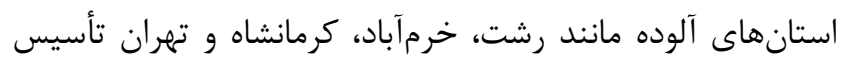

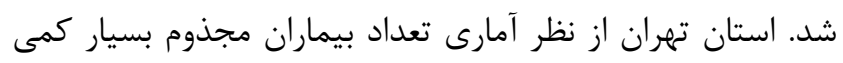

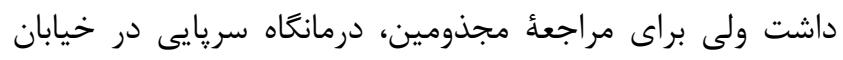

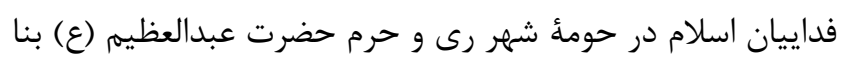

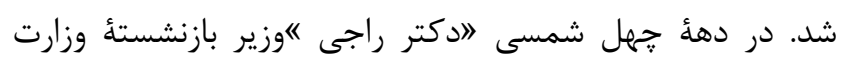

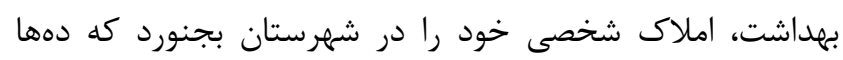

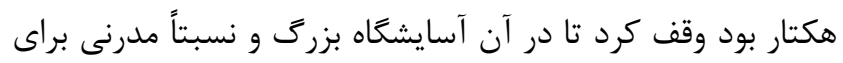

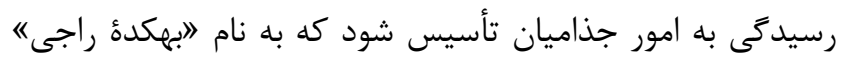

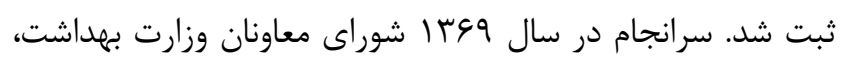

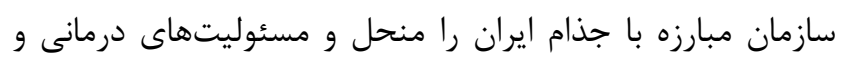

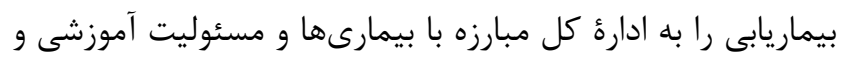

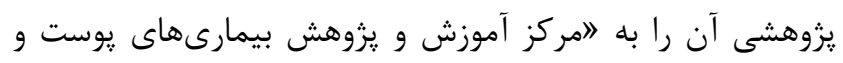

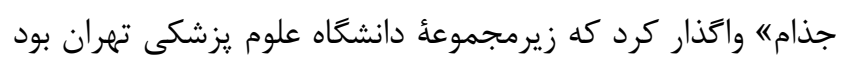

براساس اعلام سازمان جهانى بهداشت، كشور ايران جزء

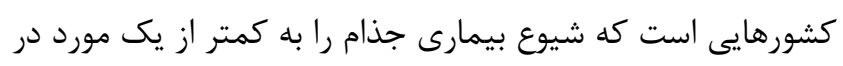

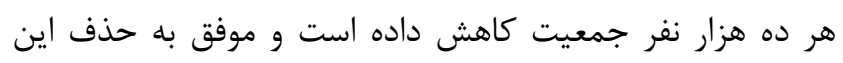

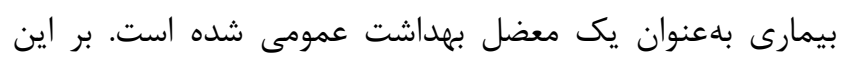

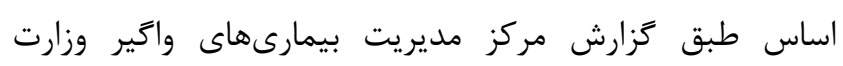

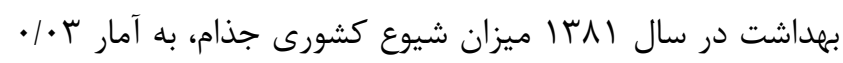

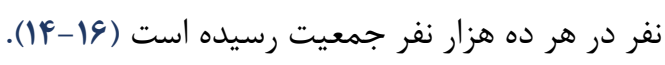

\section{طاعون}

يزشكان ايرانى از ديرباز با طاعون آشنا بودند؛ مثلا » ابوسهل

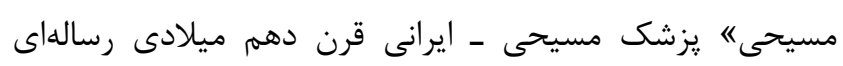

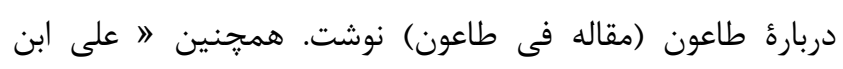

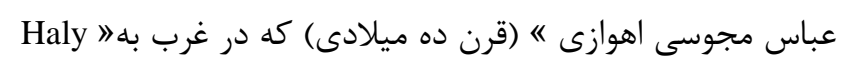

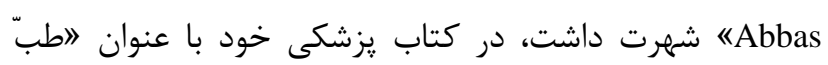

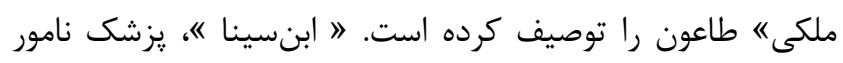

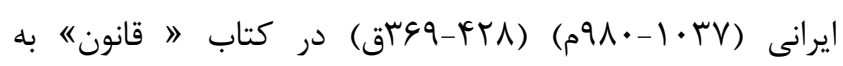

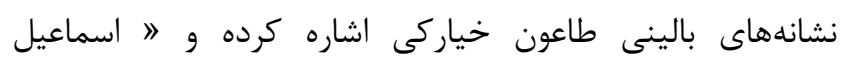

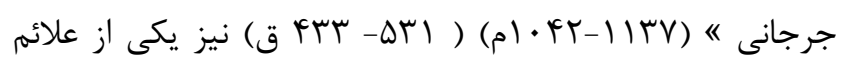

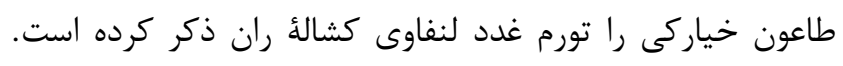

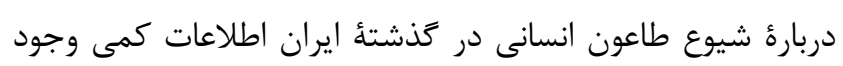

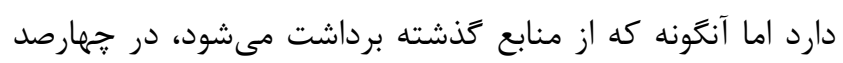

شايد بتوان وبا را در ايران ريشهكن كرد و براين اساس پيشنهاد

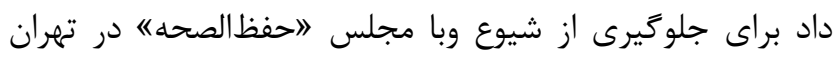

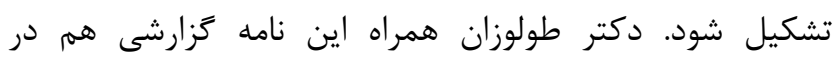

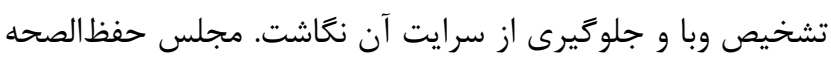

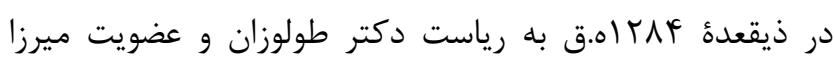

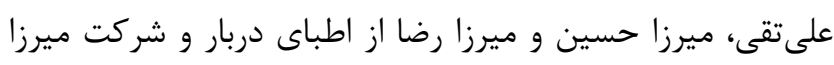

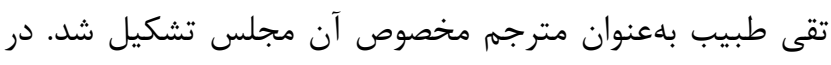

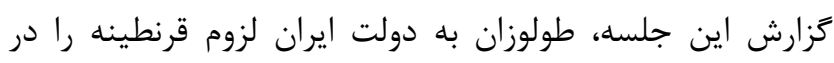

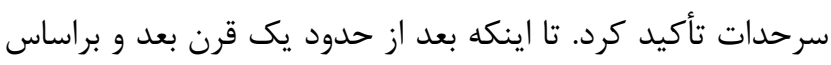

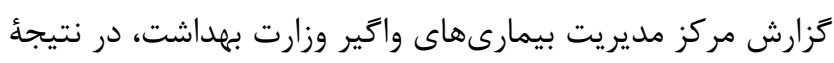

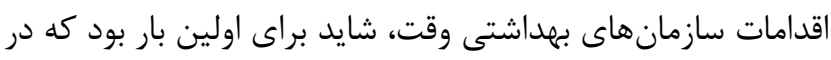

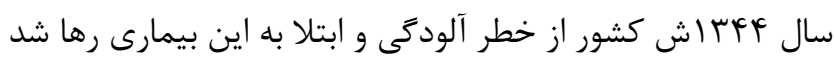

\section{جذام}

ابتلا به بيمارى جذام نيز به دفعات در ززارشهاى مورخان

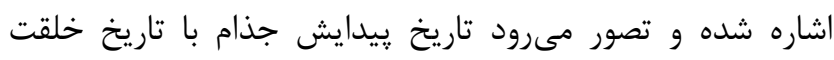

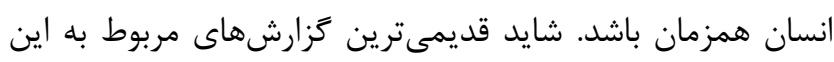

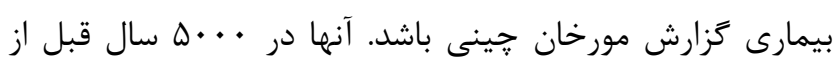

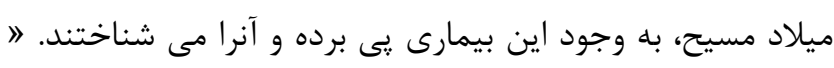

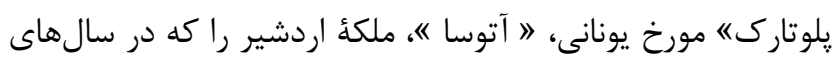

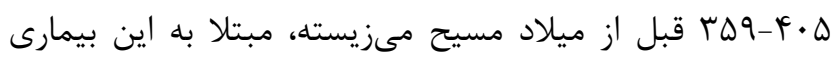

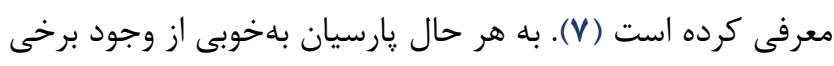

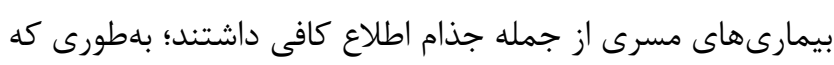

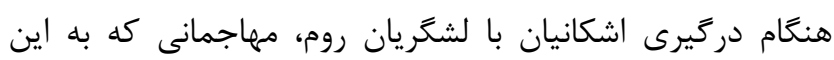

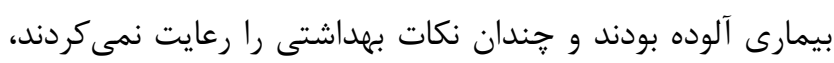

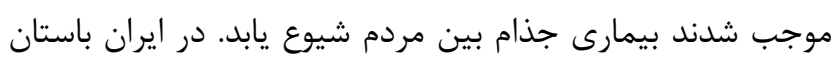

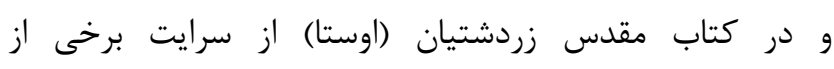

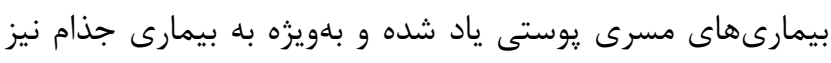

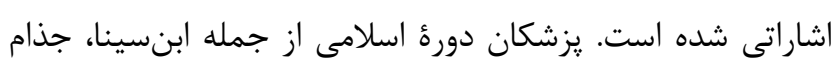

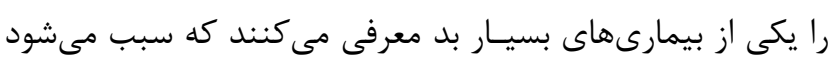

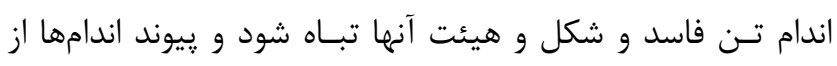

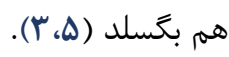
در زمان ناصرالدينشاه قاجار و و به دستور او شكاركاه

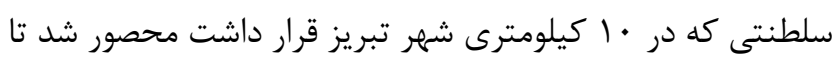

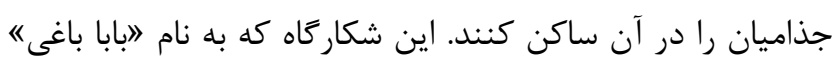

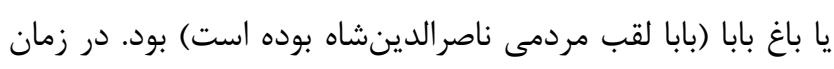

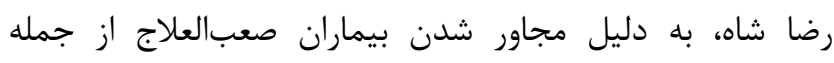
جذاميان در مشهد كه براى مداوا از سراسر كشور به خراسان بهان 


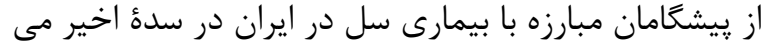

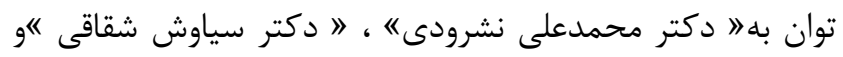

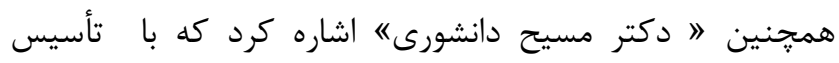

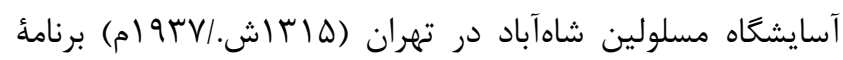

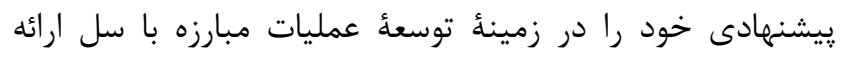

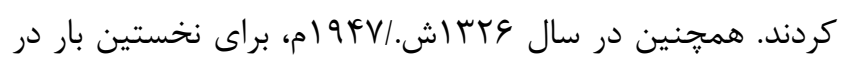

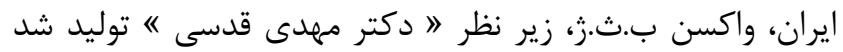

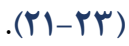

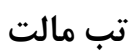

بيمارى بروسلوز يا تب مالت در سالهاى بايانى قرن نوزدهم

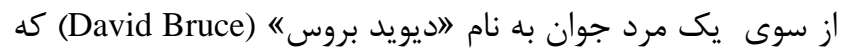

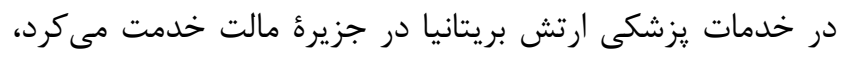

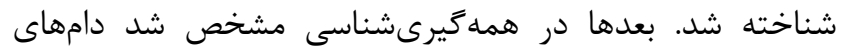

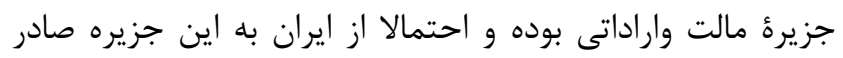

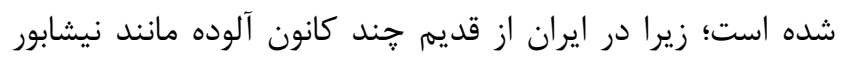

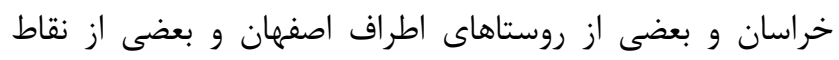

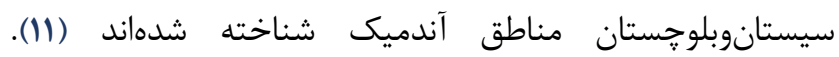
همجنين در ايران و براى اولين بار در سال الاسا كارشناسان

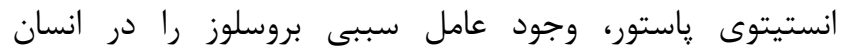

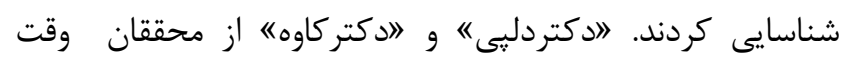

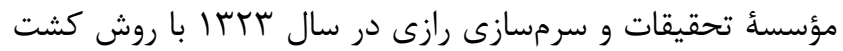
از شيردان يك كوسالأ سقطشده، بروسلا ابورتوس را رأ جدا كردند.

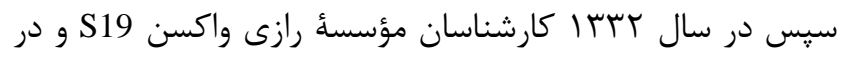

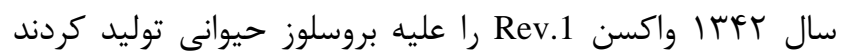

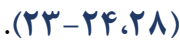

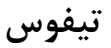

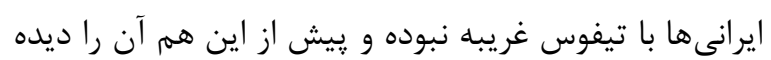

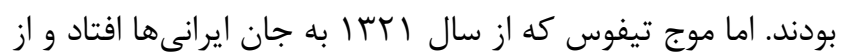
كشتهها يشته ساخت، محصول جنَ جهانى و سوغات مهمانان

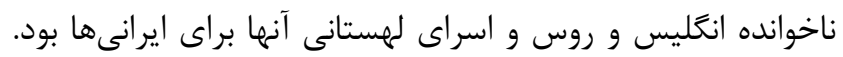

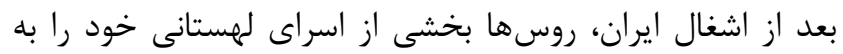

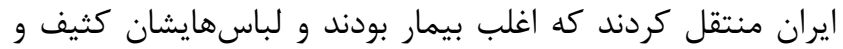

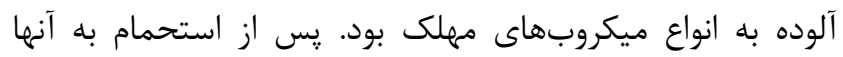

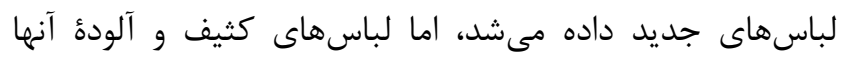
بدون آنكه ضدعفونى شود در مقابل مبلغ مختصرى به ايرانيان

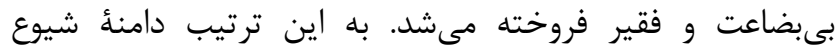

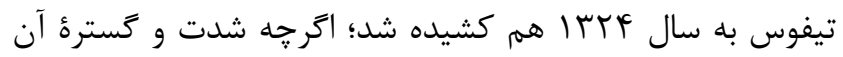

سال گذشته، ايران نيز קند بار إيدمى طاعون انسانى را تجربه

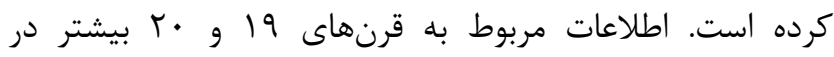
دسترس است كه نشان مى دهد شيوع اين بيمارى در قرن بيسته؛

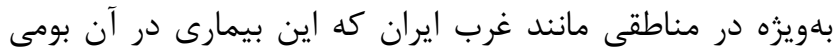
بوده، همجنان ادامه داشته است (ه).

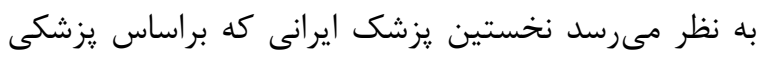

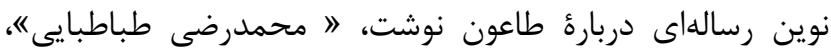
يزشك ارشد نظامى در دوره ناصرالدينشاه بود. كتاب او با عنوان

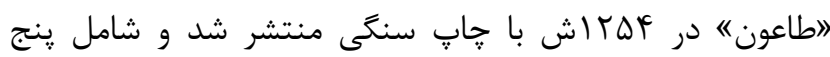
فصل و يك بِيوست بود. در اين يِيوست نوشتههاى دكتر طولوزان درباره راههاى يیشگيرى و درمان طاعون انسانى در استانهاى

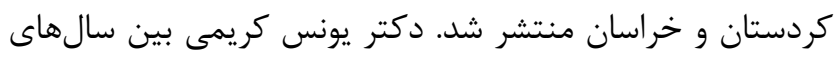

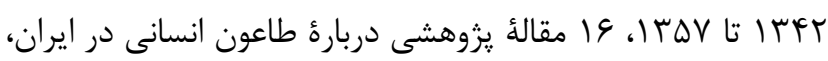
در مجلههاى معتبر بينالمللى منتشر كرد. وى همجنين كتاب

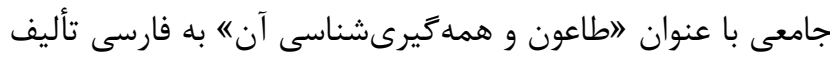

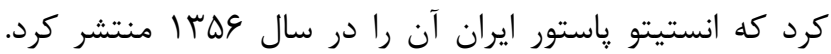

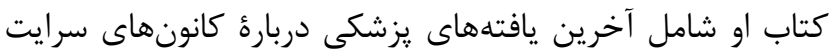

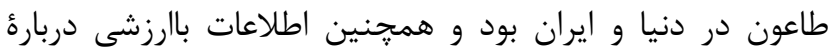

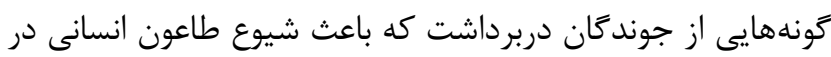

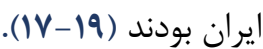

\section{سل}

پِيشينه بيمارى سل بلعنوان بيمارى مركبار در جهان، به دورة باستان بازمى كردد. در تمدنهاى كهن، سل ناخوشى شناخته

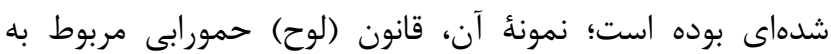

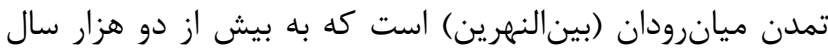

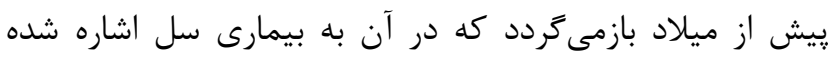

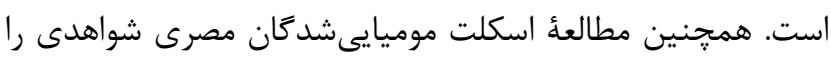
از وجود سل ستون فقرات در آنها نشان مىدهد. در كذشته

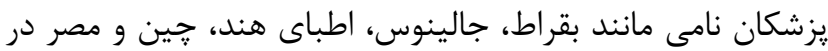

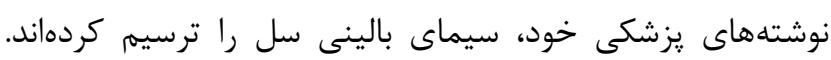

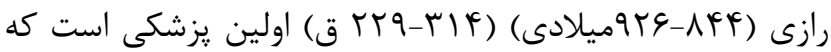

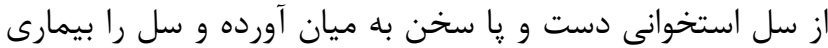

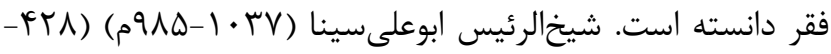
هVIrاق) نيز به بيمارى سل اشارههايى داشته و بر آن است كه سه

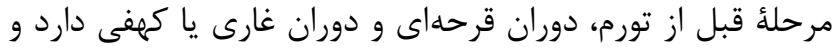

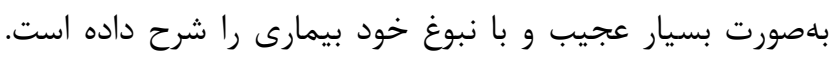

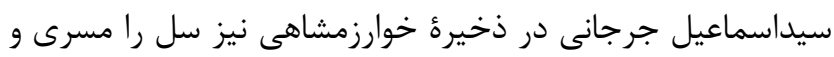

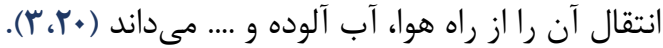


مختلفى از قبيل مشمش، مشمشه، خُنام، خنان، سُراجه و غراجه

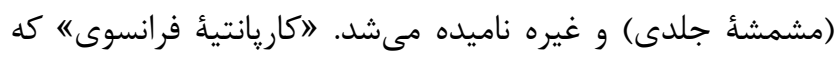

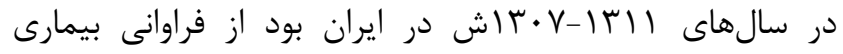

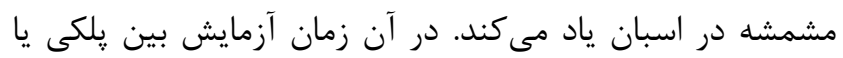

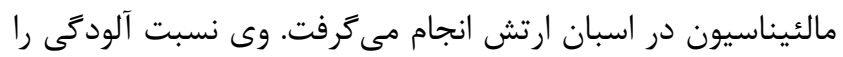

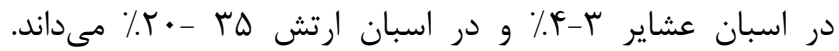

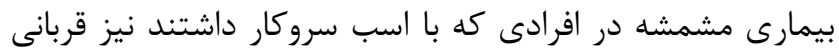

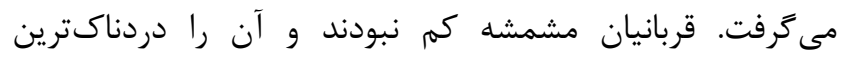
بيمارىهاى انسان مىدانستند (ه). در دوران قاجاريه، مشمشه كسترش بيشترى داشت، جنانكه خوانسارى بيمارى را بهانوبى

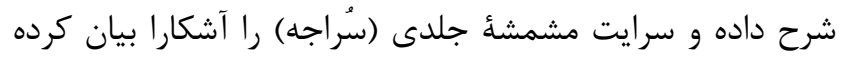

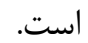

براى درمان مشمشه داروهاى تركيبى و مفرد مختلفى را از

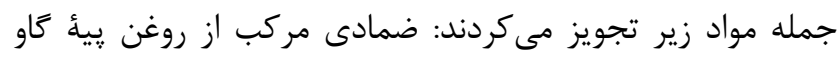

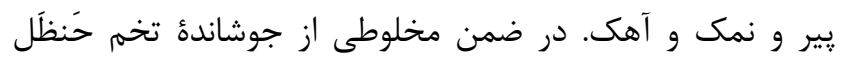
(Colocynth)، يوست بَنج (Indian Hemp, Hebane)، كنجد و و

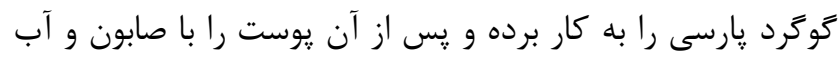

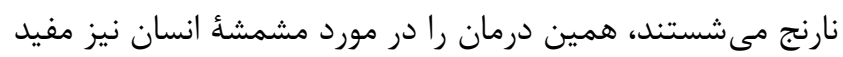

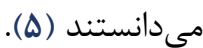

\section{مخملك}

به اعتقاد 》بيكر)(Baker) ، يزشك دوران قاجار، مخملك در

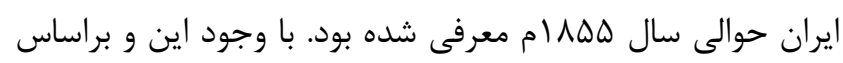

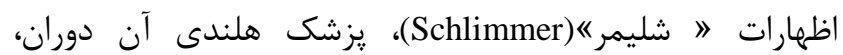
بيمارى قبل از اين تاريخ نيز در ايران روى مىداده است. حضور

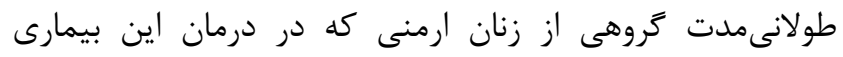

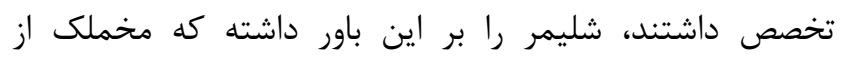
زمانهاى طولانى در ايران وجود داشته است. در نهايت، با شيوع

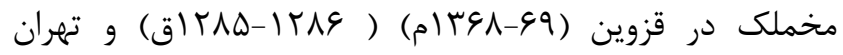

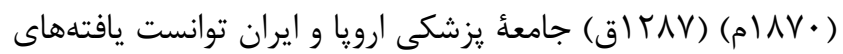

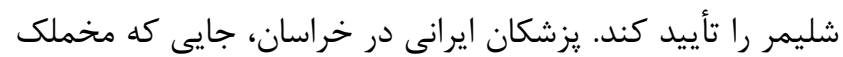
زمانى بسيار شايع بود، بين مخملك خوشخيم و و مخملك كشنده

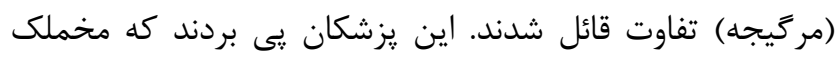

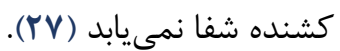

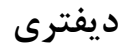

بيكر كزارش كرده كه بيمارى ديفترى يا خناق در ايران در

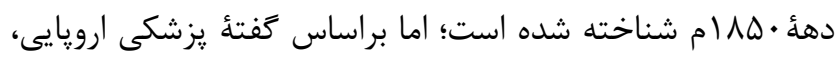

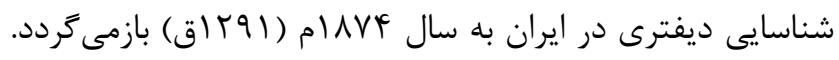

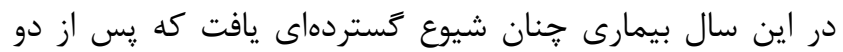

بسيار محدود شده بود. شيشهاى تيفوسى بالاخره در اين سال

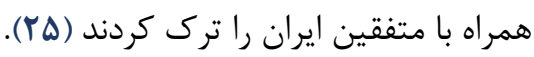

\section{تب راجعه}

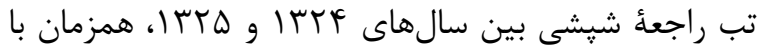

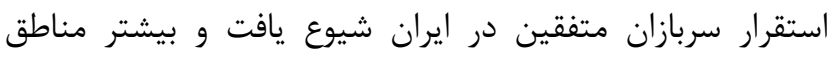

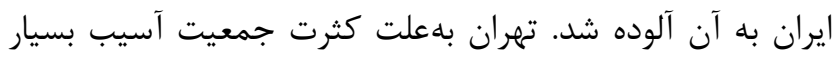
ديد و تلفات زياد داد. مشخص نيست تب راجعأ كنهاى بومي كدام كدام منطقه از ايران بوده، اما كزارشات حاكى است كه ايرانيان اين كنه

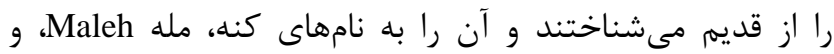

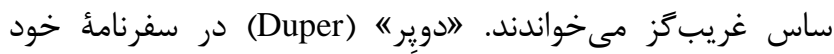

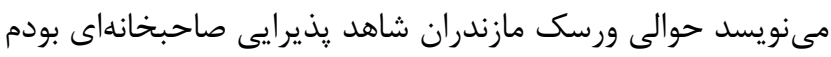

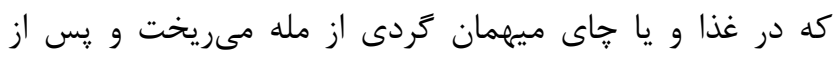

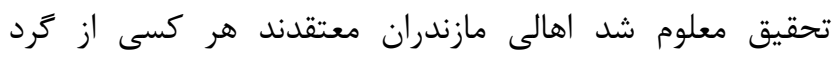

غريب زز خورده باشد، از نيش حشره مصون مىماند (

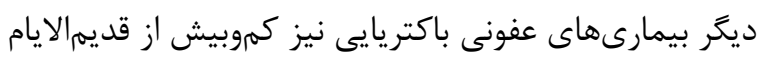

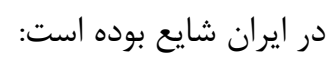

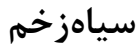

سياهزخم را ابنهندو 》انار فارسى" مىنامد و مى گويد: انار

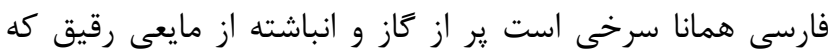

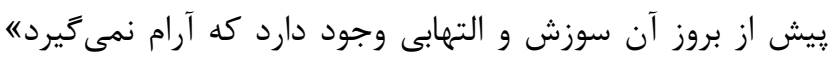

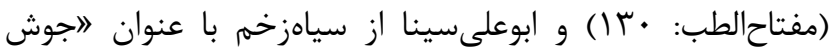

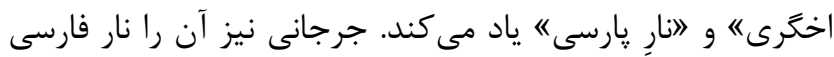

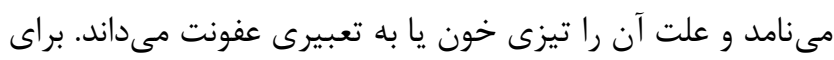
درمان سياهزخم جلدى از داروهاى مختلفى مانند يوست انار يار و

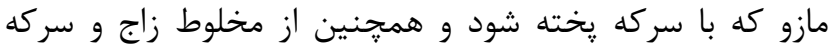

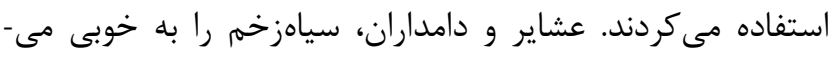
شناختند و براى درمان آن به شيؤ سنتى از علفى كوهستانى به ديه نام ريشهجينى (بيخجينى)، خاكستر يوست درخت بَنَه و مخلوط

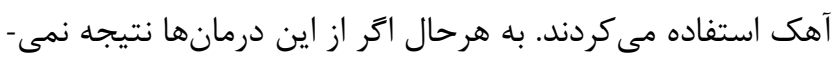

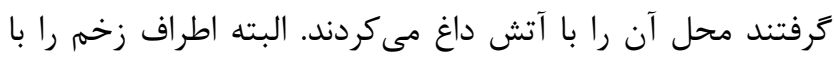
خمير نان مى يوشاندند تا از آسيب سوختكى در امان بماند. ساخت واكسن عليه شاربن حيوانى از سوى "امهدىخان ذوالرياستين" از ازئ

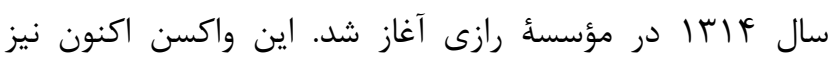

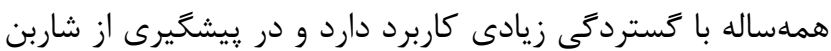

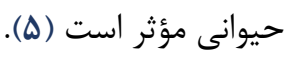

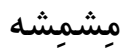

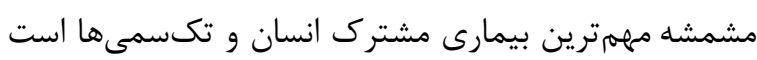
كه آن را از قديم در ايران مىشناختند. اين بيمارى به اسامى مئى 
(آوام) رسالهُ (آتشك" را به رشته تحرير درآورده است. در اين

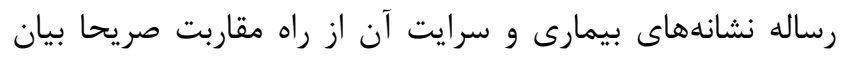

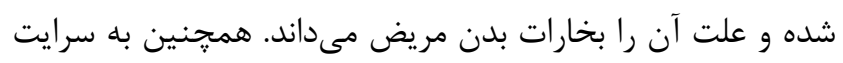

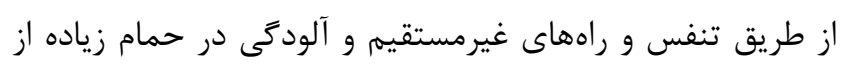

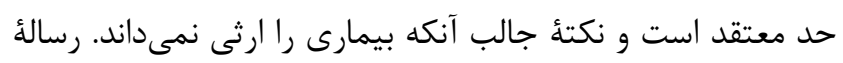

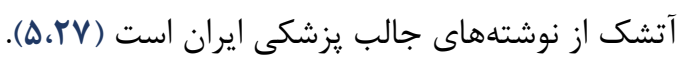

\section{تراخم}

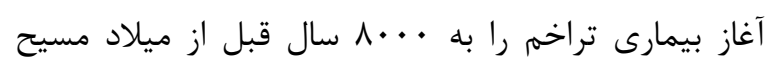

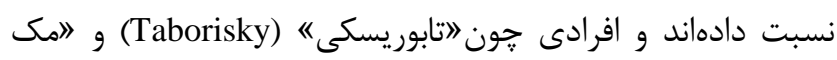

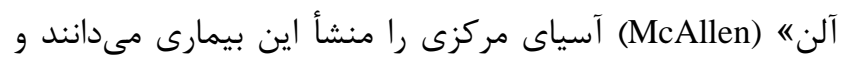

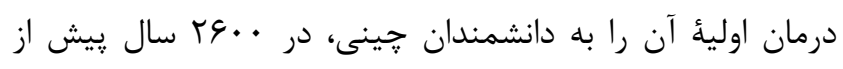

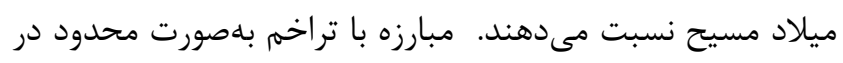

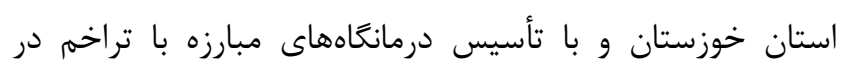

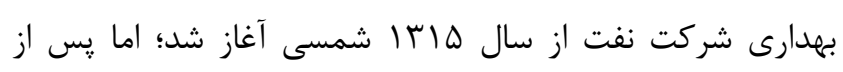

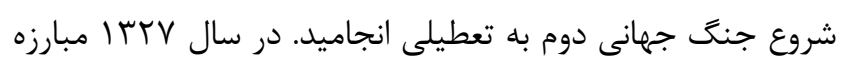

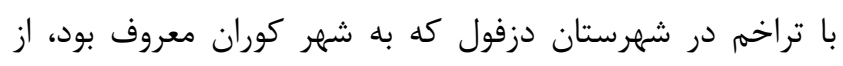

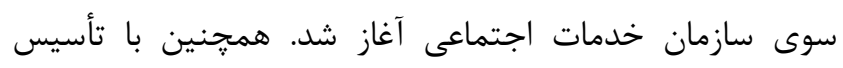

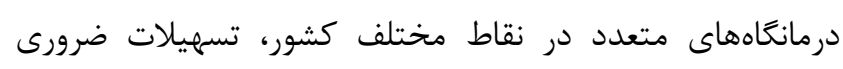

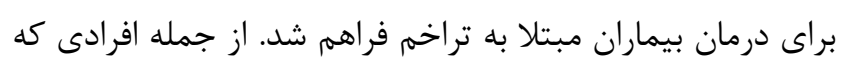

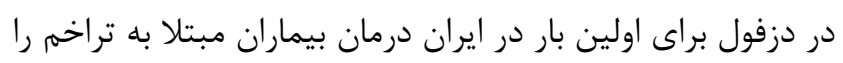

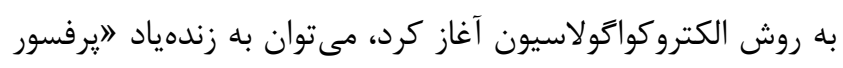

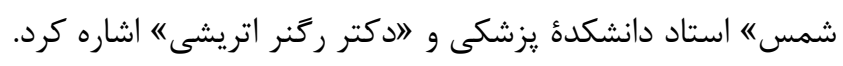

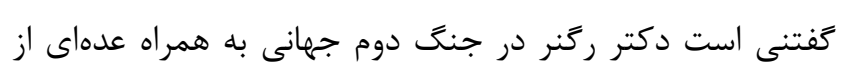

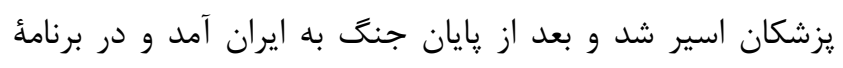

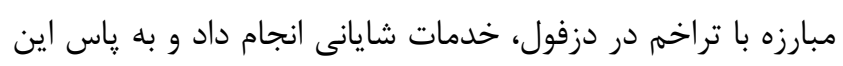

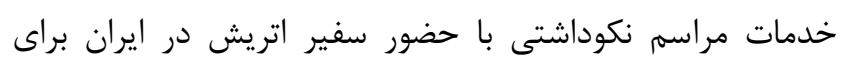
تجليل از او در دزفول بركزار شد. مبارزه با با بيمارى تراخم بات بات تشكيل

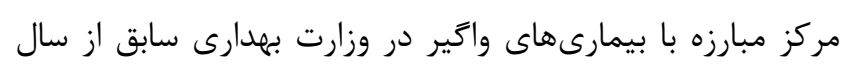

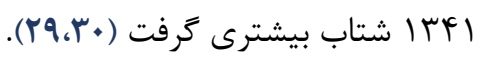

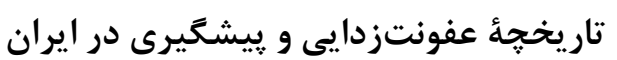

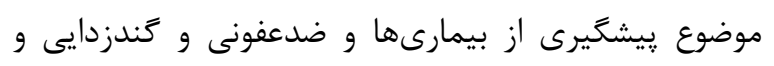

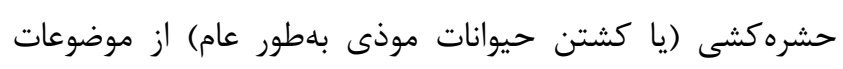

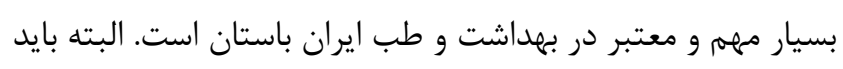

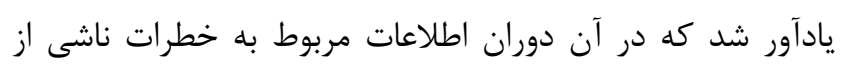

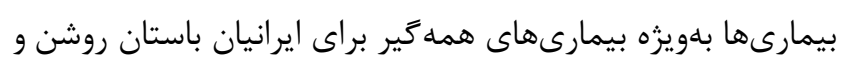

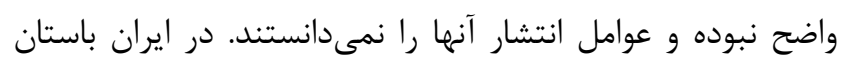

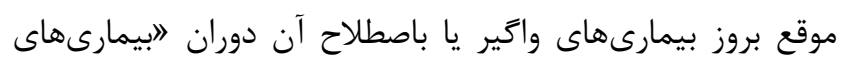

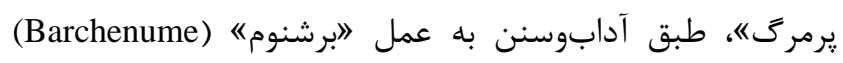

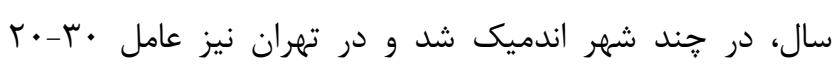

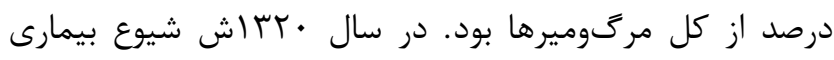

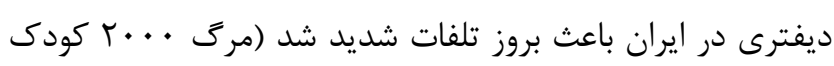

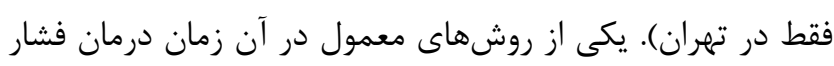

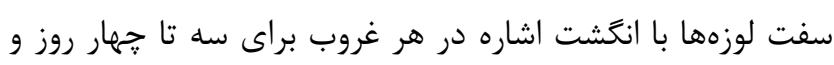

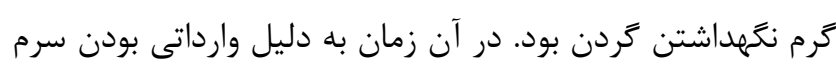

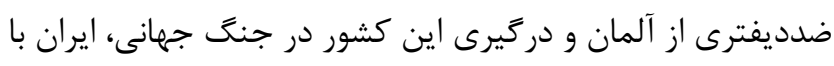

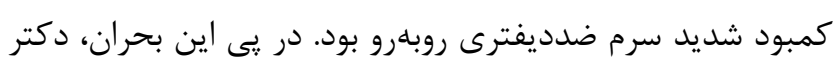

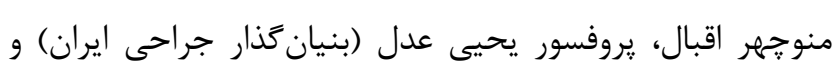

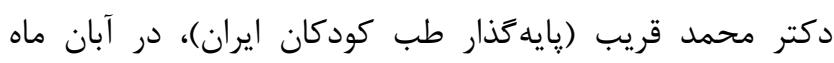

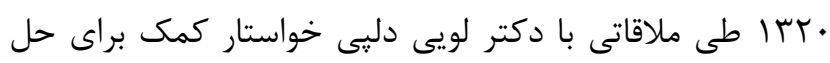

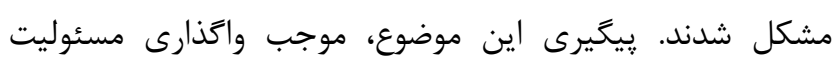

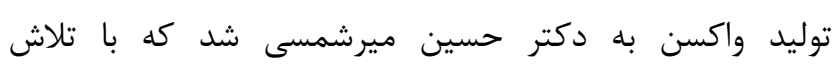

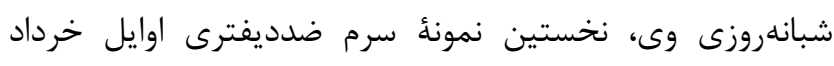

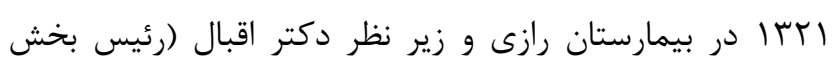

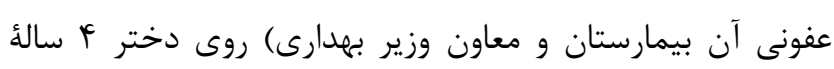

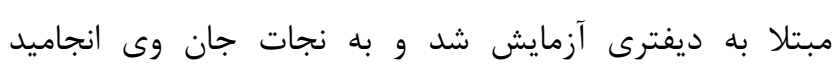

( ( $Y$. Y $\wedge)$

\section{سياهسرفه}

"ابهاءالدوله" (يكى از يزشكان برجسته ايران و جهان اسلام)

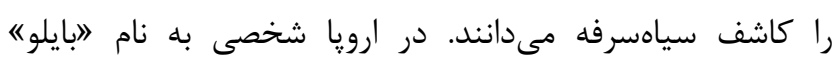
(Baillou)

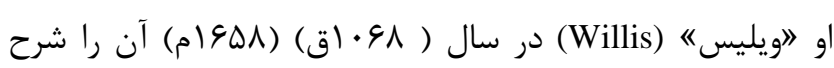

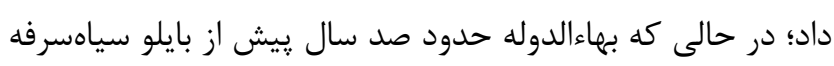

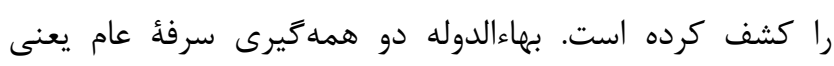

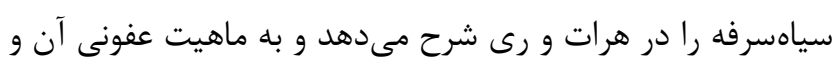

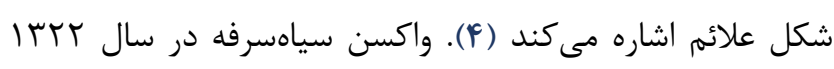

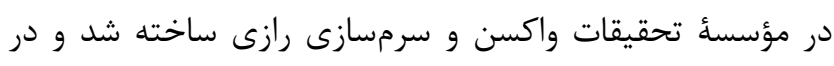

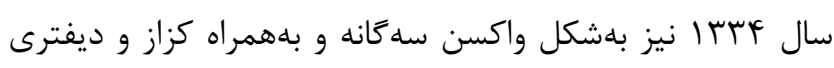

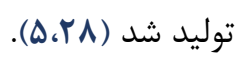

\section{سيفليس \\ سيفليس كه آن را 》ارمنى دانه" يا 》آتشك" مى تفتند، از}

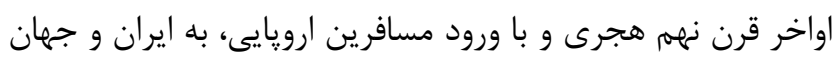

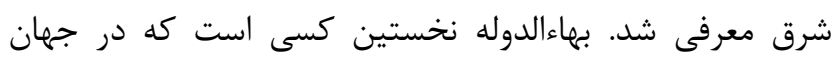

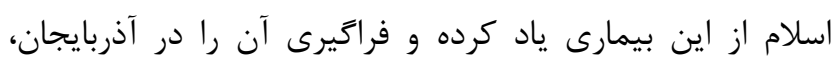

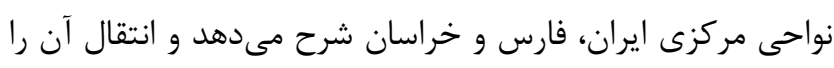

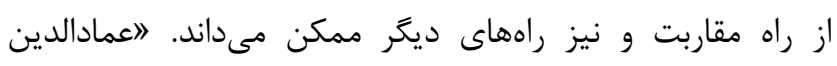

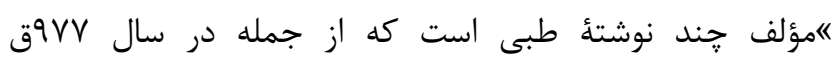


مخلوط را يشت دست، بين شصت و انغشت مجاور آن قرار داده و

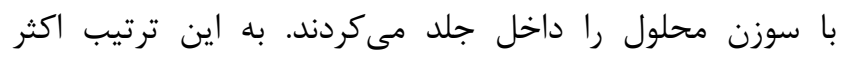

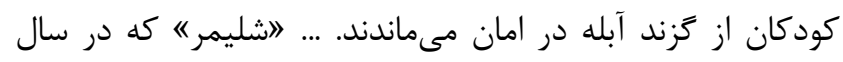

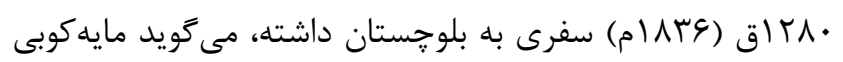

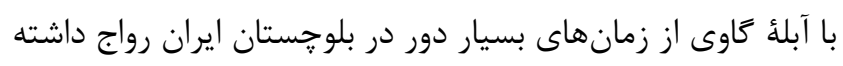

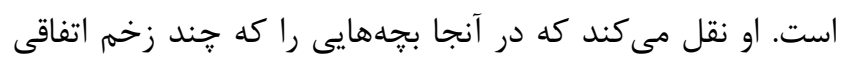

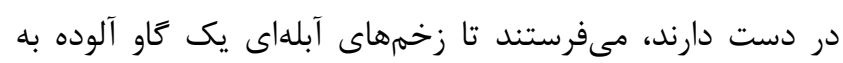

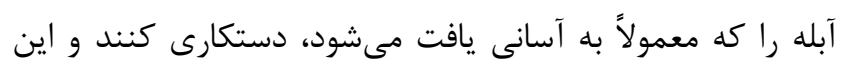

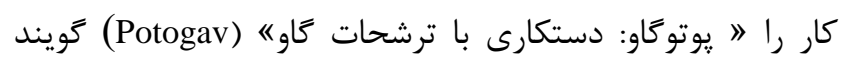

\section{نتيجه كَيرى}

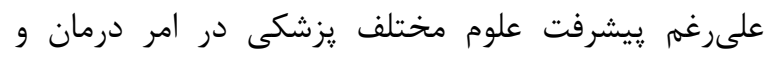

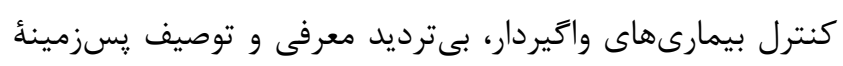

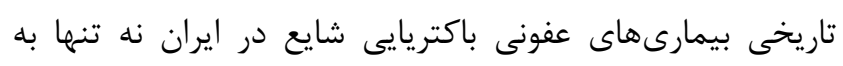

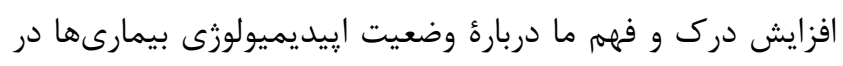

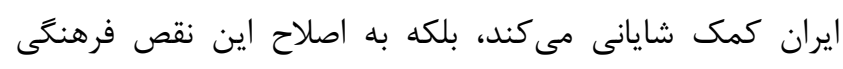

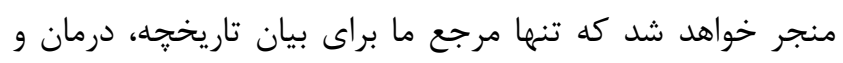

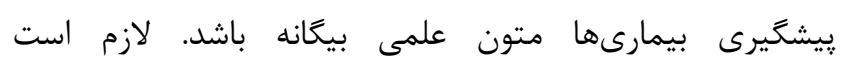

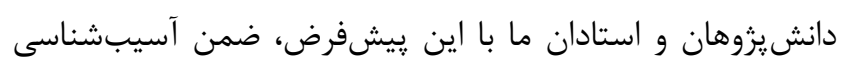

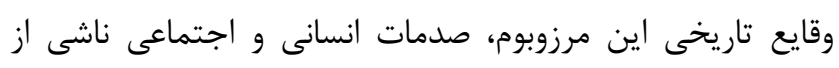

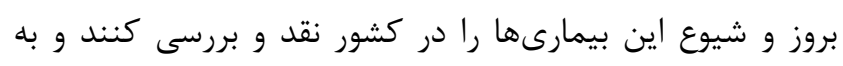

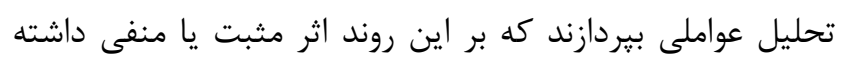

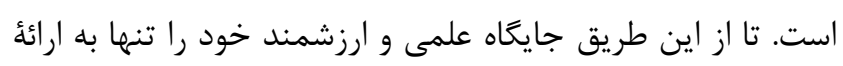

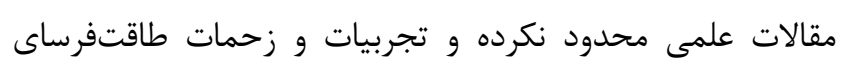

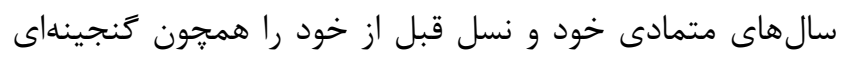
كرانبها در اختيار نسل بعد نيز قرار دهند.

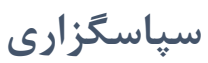

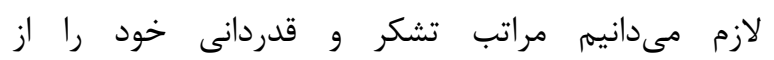
راهنمايىهاى دلسوزانٔ استاد ارجمند، جناب آقاى دكتر مانى مسلم

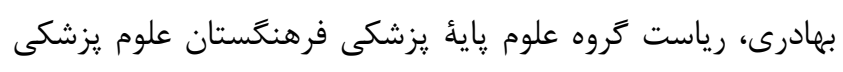

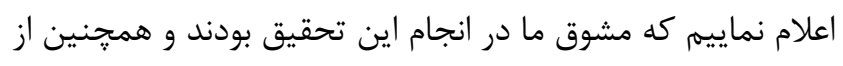

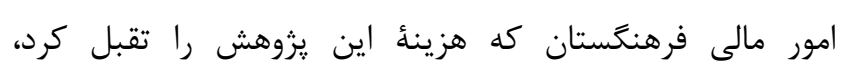

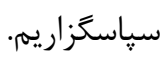

\section{تعارض منافع}

بين نويسندًان تعارض در منافع گزارش نشده است.
متوسل مىشدند كه در حقيقت تجزيه و منفرد ساختن بيماران از

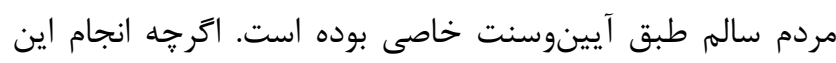

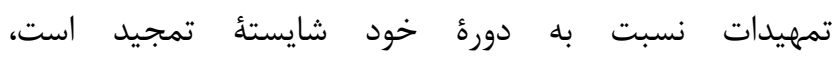

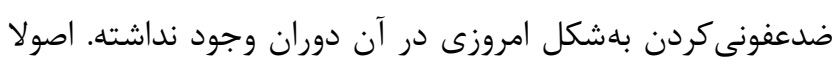

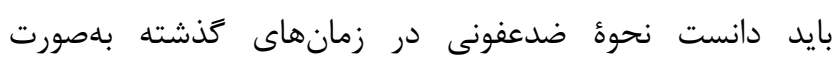

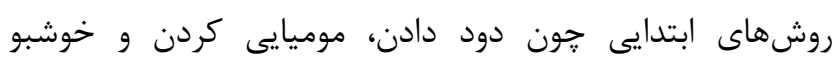

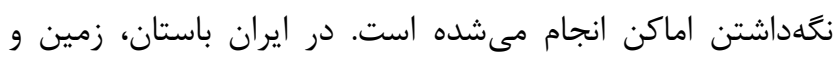

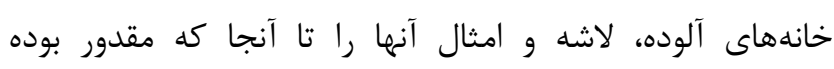

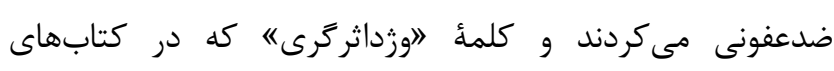

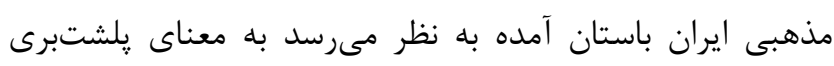

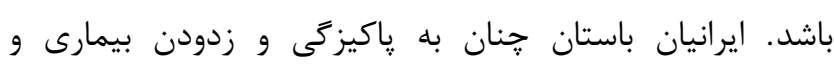

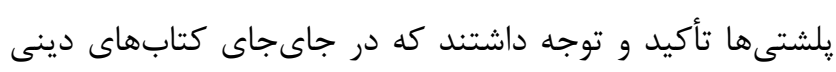

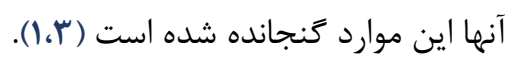

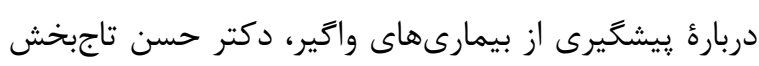

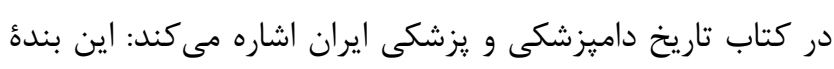

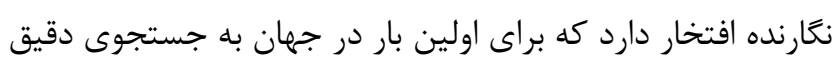

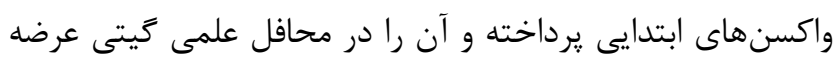

داشته است و سيس ايشان به مصاديق اين موضوع مى يردازند.

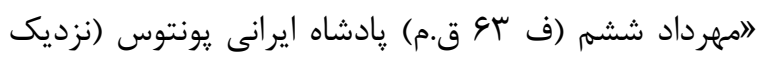

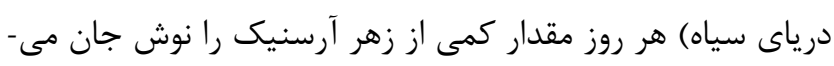

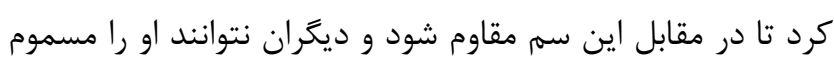

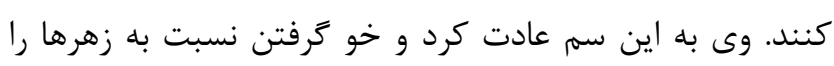

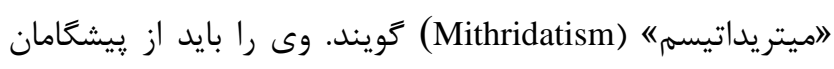

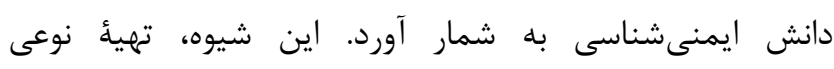

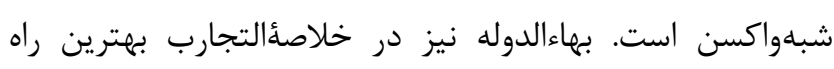

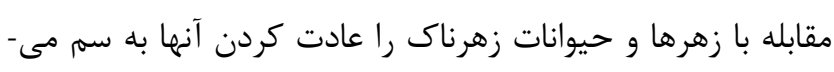

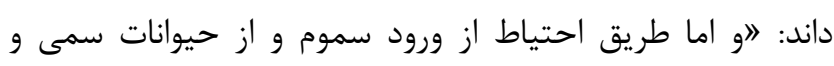

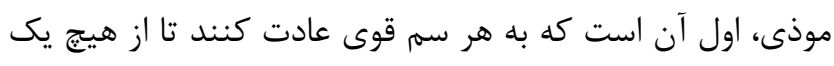

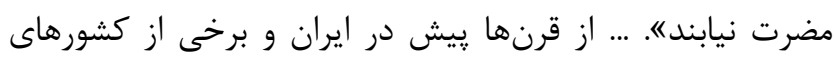

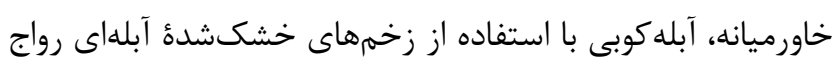

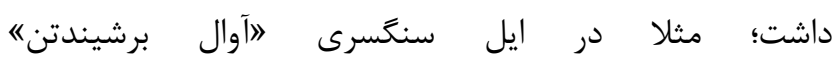
يعنى آبله خريدن يا به عبارتى آبله كوبى (Avalbarshindetan)

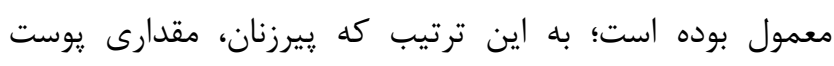

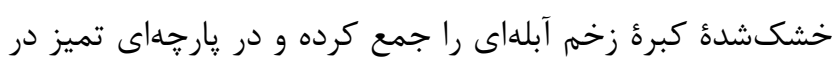

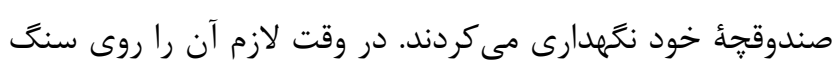

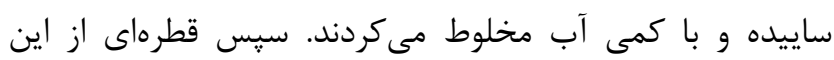




\section{References}

1. Najmabadi M. History of Medicine in Iran and the Islamic World. Volume I, History of Medicine in ancient Iran (before Islam). Tehran University: Tehran University in 1961.

2. Najmabadi M. History of Medicine in Iran and the Islamic World. Volume I, History of Medicine in Iran (after Islam). Tehran: Tehran University in 1977.

3. Kaviani P. Ancient medicine history. Tehran: AlMu'ali. 2014.

4. Nateq H. Economic and social effects of cholera in Iran. Magazine Negin, 1977; 148.

5. Tajbakhsh H. Iranian Veterinary and Medical History Volume II. Tehran: Tehran University in 1996.

6. Borel R M. Cholera epidemic in Iran 1904 (M): Some Dimensions of the Qajar Society. Translation by Farideh Farzizi, Zahra Nazarzadeh. Kherad nameh, No. 11, 2013.

7. Mostaghim M. Cholera epidemiology and its history in Iran" Doctoral Dissertation for Medical School, Tehran University of Medical Sciences. Academic year 1340-41.

8. Azizi M, Azizi F. History of Cholera Outbreaks in Iran during the 19(th) and 20(th) Centuries. Middle East J Dig Dis. 2010. 2( 1): 51-55

9. Afkhami AA. Disease and water supply: the case of cholera in 19th century Iran. Yale School of Forestry and Environmental Studies Bulletin Series. 1998;103: 206-219.

10. Lankarani KB, Alavian SM. Lessons learned from past cholera epidemics, interventions which are needed today. J Res Med Sci. 2013;18(8):630-1.

11. Mirzadeh A, Pierr Alilou Sehron N. Pearl Garden: The formation process of Baba baghi Garden. Tabriz: Publishing of Yaran. First edition, 2004

12. Saebi E. Infectious Diseases in Iran. Tehran: Ismail Saabi Publication, Second Edition, Summer 1988.

13. Ministry of Health and Medical Education Department of Health Department of Disease Management. Information and Statistics on Contagious Diseases in Iran (1356-1383) Volume 2: Tehran: Center for the Publishing of Sound, 2004

14. Tabatabai H. (An interview manual is available) specialist in dermatology and plague in 1394

15. Plague, Ministry of Health and Medical Education. Department of Health. Center for Disease Management. Information and Statistics on Contagious Diseases in Iran (1356-1381) Volume 2: Tehran: Center for the Publishing of Seda, 2004.
16. Hatami H, Towards Global Removal of Plague, Journal of Health in the field. Tehran, Iran: Shahid Beheshti University of Medical Sciences, Faculty of Health, Volume 5, Number 2, Summer 2012

17. Zardosht. H. Introduction to Iranian Medical Geography. Tehran: University Jihad in 1365.

18. Manburg G. Baltazar Plague Adventure (Biography of the Founder of the New Pasteur Institute of Iran). Translation by Manigeh Yousefi Behzadi. Tehran: Andishmand, Spring 1394

19. Azizi MH, Azizi F. A history of the human plague in Iran. Archives of Iranian medicine. 2010 November; 13( 6):563-569

20. Zia Zarifi A. The history of tuberculosis from the beginning to the present. Tehran: Printing, Naghshe jahan. Alpha publishing house. First Edition 1982.

21. Azizi MH, Bahadori M. A brief history of tuberculosis in Iran during the 19th and 20th centuries. Arch Iran Med. 2011;14(3):215-9.

22. Azizi F, Jan Ghorbani M, Hatami M, Hussein \& et al. Epidemiology and control of prenalent diseases in Iran. Tehran: Khosravi Publishing, Third Edition, 2010.

23. Nazari Gh, Forty years of research on prevalent infectious diseases in Iran. Tehran: Tehran University of Medical Sciences. Summer of 1996.

24. Zughi I. Brucellosis, Today's Medical Magazine, Third Edition, January 2014 to April 2015.

25. Safari Z. Deadly Esfand; Tehran in the Occupation of Typhus Lice, Iranian Journal of History, Sunday, Feb 26, 2015.

26. Abbasi M. Research in Medical History. Tehran: Sina Legal Cultural Institute, Legal Publishing Co. First Printing. Winter 2008.

27. Willem F. The health of people during the Qajar era. Translation by Iraj Nabi Pour. Bushehr University of Medical Sciences, Bushehr, Iran. First edition, summer 2007.

28. Razi vaccine research institute, Razi Institute over time, Qom: Maher publishing, first edition, autumn, 1394.

29. Darkatanian G, Nouraei $M$, Dehghan nejad $M$. Health Reforms in Dezful throughout the Pahlavis era (1926-1979). Ganjine-ye Asnad, 2017; 27(1): 627.

30. Mohammadpour M, Abrishami M, Masoumi A, Hashemi H. Trachoma: Past, present and future. J Curr Ophthalmol. 2016;28(4):165-9 